\title{
Genetic structure in three haploid peat mosses (Sphagnum)
}

\author{
HANS KRISTEN STENØIEN* \& SIGURD M. SÅSTAD \\ Department of Natural History, The Museum, Norwegian University of Science and Technology, N-7491 \\ Trondheim, Norway
}

\begin{abstract}
Over the past 20 years, studies have revealed levels of genetic variation in bryophytes that are similar to those found in vascular plants. This has led many to question the traditional view of bryophyte evolution, which holds that these organisms have a low evolutionary rate. RAPD and isozyme analyses were used to measure genetic variation in 18 populations of several Sphagnum taxa, with special emphasis on the bisexual $S$. lindbergii and the unisexual $S$. angustifolium, S. fallax and $S$. isoviitae. Both types of markers were found to be selectively neutral. A test of population differentiation showed no significant divergence between $S$. fallax and $S$. isoviitae growing in sympatry; these taxa were therefore treated as conspecific. Only S. angustifolium had polymorphic isozyme loci. The highest genetic variation in RAPD loci was found in S. angustifolium; the lowest in $S$. lindbergii. There seemed to be a high turnover rate of individuals in $S$. angustifolium populations. Populations of $S$. fallax coll. were strongly differentiated for RAPD markers, whereas S. angustifolium populations were only weakly differentiated for any marker, even for populations from different continents. Populations of S. lindbergii were not differentiated at all. Most studied populations did not fit the 'Conocephalum - Plagiomnium' model of bryophyte population structure. The observed patterns could best be explained by assuming a low evolutionary rate, at least in $S$. angustifolium, meaning that high levels of molecular variability seem not to be incompatible with slow evolution.
\end{abstract}

Keywords: gene flow, genetic drift, isozymes, mutation, RAPD.

\section{Introduction}

The so-called 'traditional view' of bryophyte population biology suggests that genetic variability is severely restricted in mosses and liverworts by the dominant haploid part of their life cycle, their widespread asexuality and the assumed predominant inbreeding in bisexual taxa (e.g. Anderson, 1963; Crum, 1972). Crum (1972) states that bryophytes are a genetically depleted group with limited evolutionary potential. This view is supported by palaeobotanical studies, which show that bryophytes evolved early and remained morphologically unchanged through geological time. Moreover, the existence of highly disjunct conspecific populations with little to no morphological divergence has been used to support the traditional view.

In the late 1970s and early 1980s isozyme studies performed on bryophytes revealed unexpectedly high amounts of genetic variation (e.g. Cummins \& Wyatt,

*Correspondence. E-mail: hans.stenoien@vm.ntnu.no

(C) 1999 The Genetical Society of Great Britain.
1981; Yamazaki, 1981). This led to a re-evaluation of bryophyte population biology and the evolutionary rate of these organisms. The morphological similarities through time and space are partly explained by the presence of physiological and biochemical, rather than morphological, evolution (creating sibling species) and convergent evolution (Wyatt, 1985). The so-called 'Conocephalum - Plagiomnium' model (Wyatt, 1985; Wyatt et al., 1989) has been proposed to describe the various population structures in bryophytes. Here, two species are thought to represent endpoints of a continuum: Conocephalum conicum represents low intraspecific variation, weak interpopulation differentiation and no microscale heterogeneity; whereas Plagiomnium ciliare represents high levels of variation, strong interpopulation differentiation, and microscale heterogeneity.

It is uncertain whether the high genetic variability found in bryophytes affects their evolutionary rate. The majority of isozyme loci in bryophytes behave in a selectively neutral manner according to several neutrality tests (i.e. intralocus allele frequency distributions are similar to those expected given neutrality; H. K. 
Stenøien, unpubl. data). Neutrality may thus explain the high isozyme variability of bryophytes in general. For neutral loci, the balance between mutation and random genetic drift is critical in determining the patterns of genetic variation at each locus and, together with the amount of gene flow, the multilocus genetic structure within species.

This paper investigates the impact of random genetic drift, mutation and gene flow on isozyme and RAPD variability in various Sphagnum populations. This is achieved by inferring the action of the various evolutionary forces from the observed patterns of genetic variation from the clonal to the intercontinental scale. Special emphasis is placed on clonal diversity, the estimated number of mutants generated per generation and population, differentiation between populations and number of migrants per generation, and a possible correlation between among- and within-population variation as suggested by the Conocephalum - Plagiomnium model. The main aim of this study is to establish whether patterns of genetic variation are consistent with a low evolutionary rate, as described by the traditional view of bryophyte evolution.

\section{Materials and methods}

\section{Plant material}

The bisexual Sphagnum lindbergii Schimp. ex Lindb. and the unisexual S. angustifolium (Russ.) C. Jens., S. isoviitae Flatb. and S.fallax (Klinggr.) Klinggr. (all common boreal species in the section Cuspidata) were collected from several localities in central Norway and Newfoundland (Table 1) along 30-m-long one-dimensional transects. One gametophore was sampled from points located $1 \mathrm{~m}$ apart along the transects. In the Vangsmo locality (Table 1) gametophores of $S$. fallax and $S$. isoviitae grew intermixed along the transect. All sampled gametophores were analysed isoenzymatically, whereas RAPD analyses were performed on every second gametophore along the transects. The same gametophores as those used in isozyme analysis were used in RAPD analysis.

To obtain data from a smaller spatial scale, $S$. angustifolium and $S$. lindbergii were also sampled each $10 \mathrm{~cm}$ in a 2-m 'microscale region', giving 20 sampling points altogether. Isozyme data for the unisexual $S$. flexuosum Dozy \& Molk. and S. brevifolium (Braithw.) Röll. from central Norway, S. recurvum P. Beauv. from New Jersey, and $S$. balticum (Russ.) C. Jens. from Newfoundland were included in a test for bottleneck effects (see below).

\section{Genetic analyses}

Isozyme electrophoresis was carried out according to the protocols of Cronberg (1995). His modified version of the extraction buffer of Mitton et al. (1979) was added to the fresh capitulum material and either crushed immediately or stored in an ultracold freezer for up to several months. Both methods yielded similar enzyme activities and resolution of the isozyme systems used. Menadione reductase (MNR), peroxidase (PRX) and triose-phosphate isomerase (TPI) were analysed on starch gels, using a lithium borate/tris-citrate buffer at pH 8.3/8.3 (no. 6; Wendel \& Weeden, 1989). Phosphoglucoisomerase (PGI), phosphoglucomutase (PGM) and superoxide dismutase (SOD) were analysed by isoelectric focusing on polyacrylamide gels ( $\mathrm{pH} 4.0-9.0$ ). PGI and PGM were distinctly separated on the gels and could be stained simultaneously. As the isoelectric point

Table 1 List of populations of Sphagnum angustifolium, S. fallax, S. isoviitae and S. lindbergii used in the isozyme and RAPD analyses. The Norwegian populations are separated by 5 to $20 \mathrm{~km}$, whereas the Newfoundland populations are separated by $150 \mathrm{~km}$. Norwegian and Newfoundland populations are separated by $6000 \mathrm{~km}$

\begin{tabular}{lcccc}
\hline Species & Population & Locality & Municipality & Latitude, Longitude \\
\hline S. angustifolium & 2 & Fuglemyra & Klæbu & $63^{\circ} 16^{\prime} \mathrm{N}, 10^{\circ} 25^{\prime} \mathrm{E}$ \\
& 4 & Høstadmyra & Trondheim & $63^{\circ} 25^{\prime} \mathrm{N}, 10^{\circ} 08^{\prime} \mathrm{E}$ \\
& 22 & Central region & Newfoundland & $49^{\circ} 15^{\prime} \mathrm{N}, 56^{\circ} 08^{\prime} \mathrm{W}$ \\
& 21 km N of Badger & & \\
& & Western region on Hwy.1 & Newfoundland & $49^{\circ} 24^{\prime} \mathrm{N}, 57^{\circ} 50^{\prime} \mathrm{W}$ \\
S. fallax & 1 & c. $80 \mathrm{~km}$ S of Rte 430 Junction & Klæbu & $63^{\circ} 19^{\prime} \mathrm{N}, 10^{\circ} 28^{\prime} \mathrm{E}$ \\
& 1 & Vangsmo & Trondheim & $63^{\circ} 25^{\prime} \mathrm{N}, 10^{\circ} 08^{\prime} \mathrm{E}$ \\
S. isoviitae & 3 & Høstadmyra & Trondheim & $63^{\circ} 25^{\prime} \mathrm{N}, 10^{\circ} 08^{\prime} \mathrm{E}$ \\
S. lindbergii & 5 & Høstadmyra & Klæbu & $63^{\circ} 19^{\prime} \mathrm{N}, 10^{\circ} 28^{\prime} \mathrm{E}$ \\
& 1 & Vangsmo & Trondheim & $63^{\circ} 22^{\prime} \mathrm{N}, 10^{\circ} 32^{\prime} \mathrm{E}$ \\
& 6 & Digresmyra & Klæbu & $63^{\circ} 16^{\prime} \mathrm{N}, 10^{\circ} 25^{\prime} \mathrm{E}$ \\
\hline
\end{tabular}


(pI) of PGM in these taxa is outside the $\mathrm{pH}$ range of the gels $(<\mathrm{pH} 4.0)$, these runs had to be terminated before the enzymes reached their $\mathrm{pI}$.

Isolations of DNA were performed using a modified Doyle \& Doyle (1990) procedure as described in Stenøien (1999). The samples were treated with RNase A and purified using the commercially available GeneClean II kit (Bio 101). A GeneQuant II RNA/DNA calculator (Pharmacia) was used to standardize the extracted DNA to $5 \mathrm{ng} \mu \mathrm{L}^{-1}$ in a TE buffer, as well as checking the purity of the samples. Table 2 shows the RAPD primers from Operon Technologies used in this study. A reaction volume of $25 \mu \mathrm{L}$ was prepared for each sample, consisting of $17.9 \mu \mathrm{L}$ sterile $\mathrm{ddH}_{2} \mathrm{O}, 0.1 \mu \mathrm{L}$ dNTP, $2.5 \mu \mathrm{L} 50 \%$ acetamide, $2.5 \mu \mathrm{L} \mathrm{Taq} 10 \times$ buffer, $1 \mu \mathrm{L}$ primer, $0.5 \mathrm{U}$ Taq polymerase and $1 \mu \mathrm{L}$ standardized DNA. DNA was amplified using an initial DNA denaturation step of $2 \mathrm{~min}$ at $95^{\circ} \mathrm{C}$. Then 40 cycles were run with $1 \mathrm{~min}$ denaturation at $95^{\circ} \mathrm{C}, 1 \mathrm{~min}$ annealing at $33^{\circ} \mathrm{C}$, and $2 \mathrm{~min}$ extension at $72^{\circ} \mathrm{C}$. The programme ended with $7 \mathrm{~min}$ at $72^{\circ} \mathrm{C}$ to complete the extension of the DNA, before an infinite loop at $4^{\circ} \mathrm{C}$ until electrophoresis. The amplified DNA was run out on a $1.5 \%$ agarose gel at $150 \mathrm{~V}$ for about $3 \mathrm{~h}$. After staining with ethidium bromide, the gel was photographed under long-wave UV light.

\section{Data analyses}

General genetic diversity was assessed by calculating number of haplotypes, haplotype frequencies, proportion of polymorphic loci, Nei's gene diversity at the haplotypic level, and average gene diversity over loci (Nei, 1987). Theta $(\theta)$, equal to $2 N u$, where $N$ is the effective population size and $u$ is the average mutation rate per locus per generation, was estimated in two ways. For RAPDs $\theta$ was estimated from the expected homozygosity $\left(\theta_{\mathrm{H}}\right.$; Chakraborty \& Weiss, 1991). Isozyme $\theta$ was estimated from the expected homozygosity and from the observed number of alleles $\left(\theta_{\mathrm{k}}\right.$; Ewens, 1972). The $\theta$ estimates were based on the infinite alleles model (IAM). This means that $\theta$ is underestimated in cases of undetectable 0 -alleles for RAPD markers. The

Table 2 Arbitrary RAPD primers from Operon Technologies used in this study

\begin{tabular}{llc}
\hline Primer & \multicolumn{1}{c}{$5^{\prime}$ to $3^{\prime}$} & Bp range \\
\hline$a-1$ & CAGGCCCTTC & $850-1450$ \\
$a-3$ & AGTCAGCCAC & $750-1500$ \\
$g-2$ & GGCACTGAGG & $600-1600$ \\
$g-3$ & GAGCCCTCCA & $600-2100$ \\
$g-17$ & ACGACCGACA & $650-1400$ \\
$g-18$ & GGCTCATGTG & $450-650$ \\
\hline
\end{tabular}

mean $\theta$ over all loci was calculated. Haplotypic $\theta$, denoted beta $(\beta)$, was estimated from the expected haplotypic homozygosity analogous to the $\theta_{\mathrm{H}}$ estimation. Here $u$ is the aggregated mutation and recombination rate over the studied loci.

Isozyme data were tested for selective neutrality using the Ewens-Watterson test (Ewens, 1972; Watterson, 1978) and the Ewens exact test (Ewens, 1972; Slatkin, 1994a, 1996). RAPD data were tested using Kimura \& Ohta's (1971) formula, which describes the relationship between average gene diversity over loci $\left(H_{\mathrm{e}}\right)$ and the proportion of polymorphic loci $\left(P_{\text {poly }}\right): P_{\text {poly }}=1-$ $q^{H /(1-H)}$, where $H=H_{\mathrm{e}}$ and $q$ is the criterion for polymorphism set to 0.05 . This formula expresses the probability of polymorphisms, or alternatively gene diversity, given the IAM. The IAM may result in an underestimate of $P_{\text {poly }}$ given a set of undetectable 0 -alleles in RAPDs. In other words, undetected 0 -alleles could make the system appear as if exposed to purifying selection. Agreement between observed and expected gene diversity was assessed using a chi-squared test.

The mean size of continuous haplotypes in the microscale regions could be investigated for $S$. angustifolium and S. lindbergii. The RAPD and isozyme haplotypes were combined in each studied gametophore to maximize the fingerprint resolution. A simulation test was developed to see whether the distribution of gametophores along the transects deviated from a random distribution. The sequences of gametophores along the transect were randomly permutated, and the number of occasions where two subsequent samples belonged to the same haplotype were counted in each of 999 permutations. These counts were compared to the observed data set. To see whether individual gametophores growing close together were genetically more similar than those growing further apart from each other, pairwise genetic and spatial distances were correlated using a Mantel test (Mantel, 1967). Genetic distances between gametophores were calculated as the number of loci (RAPD and isozymes) for which two individuals were different, whereas spatial differences were defined as the separation of the gametophores along the transect.

The presence of linkage disequilibrium between all pairs of loci, RAPDs and isozymes, was tested using an exact test of linkage disequilibrium (Slatkin, 1994b; Schneider et al., 1997) and a chi-squared test. The linkage disequilibrium coefficient $D$ (Lewontin \& Kojima, 1960) and the standardized linkage disequilibrium coefficient $D^{\prime}$ (Lewontin, 1964) were calculated. The percentage of linked loci in relation to the maximum number of linked loci $\left(P_{\mathrm{d}}\right)$ was estimated for each population. If $n$ is the number of polymorphic loci in a sample, then a maximum of $\left(\begin{array}{c}n \\ 2\end{array}\right)=n(n-1) / 2$ linkage 
pairs may be observed in the sample. If $d$ is the observed number of locus-pairs in linkage disequilibrium, then:

$P_{\mathrm{d}}=\left[d /\left(\begin{array}{l}n \\ 2\end{array}\right)\right] \cdot 100 \%$.

Isozyme data from all species, including data for S. flexuosum, S. brevifolium, S. recurvum and S. balticum, were tested in cases of polymorphisms and selective neutrality for possible presence of bottleneck effects using the approach described by Luikart et al. (1998). This is a test to see whether the allele frequency distribution is approximately L-shaped or not. In cases of selective neutrality, recent bottlenecks are the likely causes of mode shifts from this expected L-shape. Probabilities were estimated by procedures described by Cornuet \& Luikart (1997).

The fixation index $F_{\mathrm{ST}}$ (Weir \& Cockerham, 1984) was calculated for all pairs of conspecific populations. The significance of $F_{\mathrm{ST}}$ was tested using the nonparametric permutation approach described by Excoffier et al. (1992). The absolute number of migrants exchanged between two populations $M$ (equal to $\mathrm{Nm}$, where $N$ is the effective population size and $m$ is the migration rate), was estimated for both RAPD and isozyme data using the equilibrium relationship $M=\left(1-F_{\mathrm{ST}}\right) / 2 F_{\mathrm{ST}}$ (Wright, 1951). The relationship between $m$ and $u$ (equal to the migration rate and the mutation rate, respectively), was assessed by dividing $M$ by expected $\theta$ (divided by 2) estimated over loci. For isozyme data the maximum likelihood estimator $\theta_{\mathrm{k}}$ was used. Raymond \& Rousset's (1995) exact test of population differentiation was performed. Here the hypothesis of random distribution of $k$ different haplotypes among $r$ populations was tested by an $r \times k$ contingency table approach analogous to Fisher's exact test on a $2 \times 2$ contingency table (Schneider et al., 1997).

The above estimations and calculations were performed using the programs ARLEQUIN ver. 1.1 (Schneider et al., 1997), BOTTLENECK ver 1.1.03 (Cornuet \& Luikart, 1997) and NTSYS PC ver. 2.00 (Rohlf, 1997).

\section{Results}

Altogether nine isozyme loci were scored for each population. Peroxidase (PRX) displayed three zones of activity in all taxa and these were interpreted as three loci. Superoxide dismutase (SOD) displayed two zones of activity interpreted as two loci, with typical heterodimers in the slowest migrating zone in $S$. lindbergii implying a duplication. The remaining enzyme systems (MNR, PGI, PGM and TPI) all yielded one zone of activity in all taxa interpreted as one locus. Although prolonged staining sometimes gave additional fainter bands, these were variable in expression and were omitted from analysis. Regarding RAPDs, bands were scored as either present (1) or absent (0), representing the two allelic states for each marker locus. Only bright, unambiguous bands, or similarly, unquestionable lack of bands, were scored. Loci that were ambiguous in more than $10 \%$ of the samples for one species, were excluded from analysis. For each taxon, 20-22 RAPD loci were scored. The isozyme and RAPD data obtained in this study are also used by Såstad et al. (1999) for assessing the taxonomic relationships among the taxa in question.

Raymond and Rousset's test for population differentiation failed to reveal significant differentiation between S. fallax and S. isoviitae in sympatry at the Vangsmo locality (populations 1 and 11, respectively). As several experimental studies also show that these two taxa are conspecific (Stenøien et al., 1997; Såstad et al., 1999), they are treated collectively here ( $S$. fallax coll.), and the Vangsmo locality is treated as comprising one population (population 1).

None of the isozyme loci deviated significantly from neutrality according to the Ewens-Watterson and the Ewens exact tests. For the RAPD data, the value from the chi-squared distribution is equal to unity, indicating no deviation from neutrality.

Summaries of standard diversity indices and molecular indices are shown in Table 3 (RAPD data) and Table 4 (isozyme data). It is clear for both frequency of polymorphic loci and average gene diversity that $S$. angustifolium is more variable than S. fallax coll., which, in turn, is more variable than $S$. lindbergii. This is the case for both RAPD and isozyme data and is reflected in the single-locus $\theta$ estimates. It is unlikely that the estimate of $\theta$ for $S$. lindbergii is an underestimate caused by undetectable 0 -alleles, as only two and one loci are found to be polymorphic in populations 6 and 7 , respectively, and the 0 -alleles have, at most, a frequency of 0.06 . The haplotypic $\beta$ is much higher than the singlelocus $\theta$ in all three species.

Clonal patterns were investigated for $S$. angustifolium (populations 2 and 4) and S. lindbergii (populations 6 and 7) in the microscale regions. Altogether, 31 haplotypes were found in $S$. angustifolium and three in $S$. lindbergii. No significant correlation was found between genetic and spatial distance in either species, and in S. angustifolium the various haplotypes were found all along the transects. Significant clustering of gametophores in clone groups was found only in one $S$. angustifolium population. Uniformity could not be evaluated as many haplotypes at low frequency yield a highly skewed frequency distribution. For $S$. angustifolium the mean and standard deviation of the size of continuous haplotypes in the microscale region was $12.3 \pm 4.4 \mathrm{~cm}$ in population 2 , and $15.8 \pm 11.6 \mathrm{~cm}$ in 
Table 3 Standard diversity indices and molecular indices for RAPD data for the populations of the studied Sphagnum species

\begin{tabular}{|c|c|c|c|c|c|c|c|c|}
\hline Species & Populations & $\begin{array}{l}\text { Sample } \\
\text { size }\end{array}$ & $\begin{array}{c}\text { Number } \\
\text { of } \\
\text { haplotypes }\end{array}$ & $\begin{array}{l}\text { Frequency of } \\
\text { polymorphic } \\
\text { loci }\end{array}$ & $\begin{array}{l}\text { Haplotype } \\
\text { diversity } \\
( \pm \mathrm{SD})\end{array}$ & $\begin{array}{l}\text { Average gene } \\
\text { diversity } \\
( \pm \mathrm{SD})\end{array}$ & $\begin{array}{l}\text { Haplotypic } \beta_{\mathrm{H}} \\
\quad( \pm \mathrm{SD})\end{array}$ & $\begin{array}{c}\text { Mean locus } \theta_{\mathrm{H}} \\
( \pm \mathrm{SE})\end{array}$ \\
\hline S. angustifolium & 4 & 32 & 8 & 0.316 & $0.869 \pm 0.024$ & $0.096 \pm 0.063$ & $5.508 \pm 1.271$ & $0.121 \pm 0.012$ \\
\hline \multirow[t]{2}{*}{ S. fallax coll. } & 1 & 30 & 5 & 0.222 & $0.662 \pm 0.073$ & $0.072 \pm 0.051$ & $1.487 \pm 0.502$ & $0.082 \pm 0.010$ \\
\hline & 3 & 14 & 2 & 0.056 & $0.363 \pm 0.130$ & $0.020 \pm 0.023$ & $0.424 \pm 0.239$ & $0.024 \pm 0.006$ \\
\hline \multirow[t]{2}{*}{ S. lindbergii } & 6 & 33 & 3 & 0.105 & $0.174 \pm 0.086$ & $0.009 \pm 0.014$ & $0.157 \pm 0.094$ & $0.008 \pm 0.001$ \\
\hline & 7 & 33 & 2 & 0.053 & $0.220 \pm 0.087$ & $0.012 \pm 0.016$ & $0.210 \pm 0.106$ & $0.011 \pm 0.003$ \\
\hline
\end{tabular}

Table 4 Standard diversity indices and molecular indices for isozyme data for the populations of the studied Sphagnum species

\begin{tabular}{|c|c|c|c|c|c|c|c|c|c|}
\hline Species & $\begin{array}{c}\text { Popula- } \\
\text { tions }\end{array}$ & $\begin{array}{l}\text { Sample } \\
\text { size }\end{array}$ & $\begin{array}{c}\text { Number } \\
\text { of } \\
\text { haplotypes }\end{array}$ & $\begin{array}{c}\text { Frequency } \\
\text { of } \\
\text { polymorphic } \\
\text { loci }\end{array}$ & $\begin{array}{l}\text { Haplotype } \\
\text { diversity } \\
( \pm \mathrm{SD})\end{array}$ & $\begin{array}{l}\text { Average } \\
\text { gene } \\
\text { diversity } \\
( \pm \mathrm{SD})\end{array}$ & $\begin{array}{c}\text { Haplotypic } \\
\beta_{\mathrm{H}} \\
( \pm \mathrm{SD})\end{array}$ & $\begin{array}{l}\text { Mean } \\
\text { locus } \theta_{\mathrm{H}} \\
( \pm \mathrm{SE})\end{array}$ & $\begin{array}{c}\text { Mean } \\
\text { locus } \theta_{\mathrm{k}} \\
( \pm \mathrm{SE})\end{array}$ \\
\hline \multirow[t]{3}{*}{ S. angustifolium } & 2 & 43 & 9 & 0.375 & $0.800 \pm 0.036$ & $0.142 \pm 0.104$ & $3.162 \pm 0.768$ & $0.198 \pm 0.044$ & $0.167 \pm 0.031$ \\
\hline & 4 & 41 & 9 & 0.375 & $0.768 \pm 0.055$ & $0.173 \pm 0.121$ & $2.591 \pm 0.852$ & $0.272 \pm 0.055$ & $0.169 \pm 0.031$ \\
\hline & 22 & 12 & 6 & 0.250 & $0.849 \pm 0.074$ & $0.169 \pm 0.126$ & $4.576 \pm 2.904$ & $0.402 \pm 0.037$ & $0.326 \pm 0.053$ \\
\hline \multirow[t]{3}{*}{ S. fallax coll. } & 1 & 56 & 1 & 0 & $0 \pm 0$ & $0 \pm 0$ & $0 \pm 0$ & $0 \pm 0$ & $0 \pm 0$ \\
\hline & 3 & 46 & 1 & 0 & $0 \pm 0$ & $0 \pm 0$ & $0 \pm 0$ & $0 \pm 0$ & $0 \pm 0$ \\
\hline & 5 & 43 & 1 & 0 & $0 \pm 0$ & $0 \pm 0$ & $0 \pm 0$ & $0 \pm 0$ & $0 \pm 0$ \\
\hline \multirow[t]{2}{*}{ S. lindbergii } & 6 & 45 & 1 & 0 & $0 \pm 0$ & $0 \pm 0$ & $0 \pm 0$ & $0 \pm 0$ & $0 \pm 0$ \\
\hline & 7 & 45 & 1 & 0 & $0 \pm 0$ & $0 \pm 0$ & $0 \pm 0$ & $0 \pm 0$ & $0 \pm 0$ \\
\hline
\end{tabular}

population 4, whereas in $S$. lindbergii it was $28.6 \pm 22.7 \mathrm{~cm}$ in population 6 , and $200.0 \pm 0.0 \mathrm{~cm}$ in population 7 .

The amount of linkage disequilibrium was high in all populations for which it could be calculated (two populations of $S$. angustifolium and S.fallax coll.; Table 5). Mean $P_{\mathrm{d}}$ values were $21.2 \%$ in $S$. angustifolium and $16.7 \%$ in S.fallax. Altogether, 12 populations and nine enzyme systems were studied in the test for bottlenecks. Even though some populations exhibited a shifted mode from the expected L-shaped allele frequency distribution, none of these was significant (significance level $\gamma=0.05$ ), indicating that bottlenecks are not a common phenomenon in these populations.

The various species studied showed different patterns of interpopulation differentiation (Table 6). The average $F_{\text {ST }}$ values for RAPD data range from 0.536 ( $S$. fallax coll.) to 0 (S. lindbergii). Populations of $S$. angustifolium were also only slightly differentiated $\left(F_{\mathrm{ST}}=0.132\right)$. The number of migrants per generation $(M)$ is estimated at
3.289 in $S$. angustifolium and 0.433 in S. fallax coll. It is not possible to estimate $M$ in $S$. lindbergii. Populations of $S$. fallax coll. separated by a few hundred metres (populations 3 and 5) are more strongly differentiated than are populations separated by $20 \mathrm{~km}$ (populations 1 and 5). The relationship between mean locus migration rate and mean locus mutation rate shows that the migration rate is $\approx 25$ times higher than the mutation rate in $S$. angustifolium, and eight times higher in $S$. fallax. For isozyme markers, the mean $F_{\mathrm{ST}}$ was 0.223 in S. angustifolium (including populations 22 and 24), higher than for the RAPD data. Populations of $S$. angustifolium from different continents were not more strongly differentiated than populations situated in the same geographical region. The mean number of migrants per generation is estimated at 1.646, and the migration rate is approximately seven times higher than the mutation rate for isozyme loci. All the S. angustifolium and $S$. fallax coll. populations are significantly differentiated $(P<0.05)$, but the $S$. lindbergii populations are $\operatorname{not}(P=0.686)$. 
Table 5 Linkage disequilibrium coefficients $(D)$ for two Sphagnum angustifolium and two $S$. fallax populations. Both RAPD and isozyme loci are used in the computations. Only $D$ values significant according to the exact test for linkage disequilibrium (100 000 permutations) and the chi-squared test $(P<0.05)$ are presented. The standardized $D$ values $\left(D^{\prime}\right)$ are all equal to one. Proportion of linked loci relative to the maximum number of linked loci $\left(P_{\mathrm{d}}\right)$ for each population is given below

\begin{tabular}{|c|c|c|c|c|c|c|c|c|c|}
\hline \multirow[b]{2}{*}{ Locus } & \multicolumn{3}{|c|}{ S. angustifolium population 2} & \multicolumn{4}{|c|}{ S. angustifolium population 4} & \multirow{2}{*}{$\begin{array}{c}\text { S. fallax coll. } \\
\text { population } 1 \\
\text { a3-850 }\end{array}$} & \multirow{2}{*}{$\begin{array}{c}\text { S. fallax coll. } \\
\text { population } 5 \\
\text { a3-850 }\end{array}$} \\
\hline & $a 1-850$ & prx-1 & pgm-1 & $g 2-650$ & $g 2-600$ & prx-1 & prx $x-2$ & & \\
\hline al-950 & 0.083 & - & 0.057 & - & - & 0.055 & 0.020 & - & - \\
\hline$a 3-800$ & - & - & - & - & - & - & - & 0.196 & 0.116 \\
\hline$g 2-1100$ & - & 0.119 & 0.064 & 0.098 & 0.180 & 0.094 & 0.047 & - & - \\
\hline$g 2-700$ & - & 0.020 & - & - & 0.088 & - & - & - & - \\
\hline$g 2-650$ & - & - & - & - & - & 0.109 & 0.055 & - & - \\
\hline$g 3-1950$ & - & - & - & - & - & 0.094 & 0.109 & - & - \\
\hline prx-1 & - & - & - & - & - & - & 0.094 & - & - \\
\hline$P_{\mathrm{d}}$ & & $9.1 \%$ & & & $33.3 \%$ & & & $16.7 \%$ & $16.7 \%$ \\
\hline
\end{tabular}

\section{Discussion}

\section{Variation within populations}

Studies of Sphagnum have demonstrated high withinand among-species genetic variability (e.g. Shaw \& Srodon, 1995; Cronberg, 1996a). Cronberg (1996a) reported lower genetic variability in bisexual vs. unisexual species in section Acutifolia. This may be explained by a higher degree of inbreeding in bisexual species and agrees with results presented here. The present study demonstrates large differences in within-population variation in the studied taxa. The high variability of $S$. angustifolium is comparable to regional to wide-

Table 6 Results from interpopulation analyses of the studied Sphagnum species. RAPD data are presented in the upper and isozyme data in the lower table. $F_{\mathrm{ST}}$ (and $P$ values), number of migrants $(M)$, the relation between migration and mutation equal to $M / \theta$, and $P$ values for the population differentiation test are shown. For isozyme data, the maximum likelihood estimates of $\theta$ based on sample number of alleles are used

\begin{tabular}{|c|c|c|c|c|c|c|}
\hline Species & $\begin{array}{l}\text { Population } \\
\text { pairs }\end{array}$ & $\begin{array}{c}\text { Mean locus } \\
F_{\mathrm{ST}}\end{array}$ & $P( \pm \mathrm{SD})$ & $\begin{array}{l}\text { Number of } \\
\text { migrants }(M)\end{array}$ & $\begin{array}{c}\text { Mean locus } \\
m / u\end{array}$ & $\begin{array}{l}P \text { for the exact } \\
\text { differentiation } \\
\text { test }\end{array}$ \\
\hline \multicolumn{7}{|l|}{ RAPD data } \\
\hline S. angustifolium & $2-4$ & 0.132 & $0.000 \pm 0.000$ & 3.289 & 25 & $0.000 \pm 0.000$ \\
\hline \multirow{4}{*}{ S. fallax coll. } & $1-3$ & 0.640 & $0.000 \pm 0.000$ & 0.281 & 5 & $0.000 \pm 0.000$ \\
\hline & $1-5$ & 0.366 & $0.000 \pm 0.000$ & 0.865 & 13 & $0.007 \pm 0.005$ \\
\hline & $3-5$ & 0.549 & $0.000 \pm 0.000$ & 0.411 & 12 & $0.000 \pm 0.000$ \\
\hline & Total & 0.536 & $0.000 \pm 0.000$ & 0.433 & 8 & $0.000 \pm 0.000$ \\
\hline S.lindbergii & $6-7$ & -0.007 & $0.672 \pm 0.003$ & Indeterminate & - & $0.686 \pm 0.010$ \\
\hline \multicolumn{7}{|l|}{ Isozyme data } \\
\hline \multirow[t]{7}{*}{ S. angustifolium } & $2-4$ & 0.271 & $0.000 \pm 0.000$ & 1.344 & 6 & $0.000 \pm 0.000$ \\
\hline & $2-22$ & 0.172 & $0.000 \pm 0.000$ & 2.403 & 10 & $0.000 \pm 0.000$ \\
\hline & $2-24$ & 0.317 & $0.000 \pm 0.000$ & 1.077 & 4 & $0.000 \pm 0.000$ \\
\hline & $4-22$ & 0.113 & $0.014 \pm 0.004$ & 3.943 & 16 & $0.000 \pm 0.000$ \\
\hline & $4-24$ & 0.112 & $0.039 \pm 0.006$ & 3.948 & 16 & $0.007 \pm 0.007$ \\
\hline & $22-24$ & 0.141 & $0.020 \pm 0.005$ & 3.052 & 13 & $0.049 \pm 0.009$ \\
\hline & Total & 0.223 & $0.000 \pm 0.000$ & 1.646 & 7 & $0.000 \pm 0.000$ \\
\hline \multirow[t]{4}{*}{ S. fallax coll. } & $1-3$ & - & - & Indeterminate & - & - \\
\hline & $1-5$ & - & - & Indeterminate & - & - \\
\hline & $3-5$ & - & - & Indeterminate & - & - \\
\hline & Total & - & - & Indeterminate & - & - \\
\hline S. lindbergii & $6-7$ & - & - & Indeterminate & - & - \\
\hline
\end{tabular}


spread, animal- or wind-pollinated vascular plants, whereas the variation in $S$. lindbergii is comparable to local endemic and selfing vascular plants (Hamrick \& Godt, 1989).

Variability in neutral genetic markers is determined by the relation between mutation and random genetic drift. The core determinant of population variability at individual loci is thus the balance between the mutation rate $(u)$ and the effective population size $(N)$, expressed in the parameter $\theta$. It is reasonable to assume that the substitution rate for neutral markers is similar in closely related species (Zuckerkandl \& Pauling, 1965). Therefore, variation in $\theta$ should be the result of different $N$-values for the various species. Larger $N$ results in more mutants per generation, and fewer alleles are likely to be lost because of stochastic events. For S. angustifolium and $S$. fallax coll. $\theta$ seems to be larger than for $S$. lindbergii. The ratio between the mean species $\theta$ values, estimated from RAPD data, is 14:5:1 for $S$. angustifolium, $S$. fallax coll. and $S$. lindbergii, respectively. This ratio also expresses the relationship between the $N$-values of the species, given similar mutation rates in the marker loci.

There are several possible reasons for differences in $N$ among taxa, such as fluctuating population sizes, unequal numbers of males and females, and overlapping generations. Differences in fecundity and/or inbreeding seem the most plausible explanations for the differences in genetic variation observed between unisexual and bisexual species in the present study (cf. Cronberg, 1996a). The reproductive system is not in itself an evolutionary force, as nonrandom mating creates changes in sporophyte genotype frequencies, but not in gametophytic allele frequencies. By reducing $N$, however, inbreeding may indirectly increase the probability of random fixation of alleles. Also, if reproductive mode is associated with differences in migration potential, it can behave indirectly as an evolutionary force in a population. The ratio of the haplotypic $\beta$ values is $31: 5: 1$ in S. angustifolium, S. fallax coll. and S. lindbergii, respectively. The ratio between haplotypic $\beta$ and $\theta$ estimated from individual loci is about twice as high in $S$. angustifolium vs. S. fallax coll. and S. lindbergii. One might speculate that the unisexual $S$. angustifolium experiences more events of recombination than the bisexual S. lindbergii, because of a higher degree of outcrossing in $S$. angustifolium. It is clear from the present data, however, that the amount of recombination is limited, at least in unisexual taxa. The amount of linkage disequilibrium is quite high for these species, which agrees with findings in other mosses (Shaw et al., 1987).

Previous electrophoretic studies (reviewed by Stoneburner et al., 1991) have shown that individual colonies of some mosses and liverworts contain several different haplotypes. Experiments have shown that the turnover of ramets within Sphagnum clones may be rapid and that Sphagnum stands in general are highly dynamic (Haig, 1989; as cited by Daniels, 1993). Shaw \& Srodon (1995) found a moderate level of clonal genetic variation in S. rubellum. Cronberg (1996b) found 18 haplotypes in S. capillifolium using 13 enzyme loci, and the mean clone size was $35 \pm 8 \mathrm{~cm}$ when the metric distance from the first to the last encountered representative within the transect was calculated. Some clones were spatially extensive, but others were small and grew interspersed amongst the dominant clones. Even though haplotypes tend to cluster in space (indicating vegetative growth), data from the present study suggest a high turnover and microscale movement of genes within S. angustifolium populations. This is indicated by small clone sizes, large genetic differences on a 2-m scale, and the lack of correlation between genetic and geographical distance. In the studied microscale regions of $S$. angustifolium, the clones do not seem to have the opportunity to grow undisturbed for long periods of time. A quite different pattern was observed in $S$. lindbergii, in which there was one dominant clone and two rare clones.

\section{Variation among populations}

Even though several authors claim that the gene flow potential of most bryophytes is limited (e.g. Wyatt, 1982; McQueen, 1985), many studies using indirect genetic estimation procedures have shown moderate to large numbers of migrants per generation in bryophytes (see Akiyama, 1994 for a survey). In S. angustifolium the number of migrants per generation $(M)$ is greater than unity for both isozyme and RAPD markers. In $S$. fallax coll., $M$ is less than unity, indicating the presence of local differentiation caused by genetic drift. Even between the two $S$. fallax coll. populations situated on the same mire and separated by a few hundred metres (populations 3 and 5), there are very few migrants (0.4 per generation). The relatively high amount of linkage disequilibrium in these populations suggests that much of the putative migration is caused by transfer of inbred spores or asexual fragments. It is not possible to compute $M$ for $S$. lindbergii because of nonsignificant $F_{\text {ST }}$. Differentiation tests show, however, that $S$. lindbergii populations are the only ones that are not significantly differentiated, meaning that the haplotypes are randomly distributed among the two localities. Data are limited, but this may indicate that $S$. lindbergii is even less structured than the two unisexual species in the present study. This agrees with Wyatt's (1994) conclusion that bisexual bryophyte species do not seem to be more genetically differentiated across their ranges than 
unisexual species. Thus, even though it seems that the unisexual $S$. angustifolium (and maybe $S$. fallax coll.) have larger effective population sizes than the bisexual $S$. lindbergii, the $S$. lindbergii populations may be distributed over larger geographical areas as a result of larger clone sizes and perhaps greater gene flow. Sphagnum lindbergii produces spores abundantly in each generation, and their dispersal over great distances by wind may explain the observed pattern. Also, $S$. lindbergii grows in low carpets and floating mats, where extensive movement of diaspores is possible during periods of high precipitation and snow melt. Sphagnum fallax coll. grows in moderately wet fen carpets, but still has possibilities for diaspore dispersal by rain and snow melt. On the other hand, $S$. angustifolium grows in high level lawns and hummocks, where water transport of diaspores may be more restricted. This species also produces sporophytes less frequently than either $S$. fallax coll. or S. lindbergii. One might therefore speculate that in $S$. angustifolium (as in the closely related $S$. fallax coll.) there is limited movement of genes over a certain spatial threshold and that other evolutionary forces maintain the genetic similarity between populations.

Several features could make populations genetically similar without the influence of extensive gene flow and natural selection. First, the estimated $M$-values may not represent ongoing migration processes; thus, the patterns observed may be caused by migration that occurred several hundreds or thousands of years ago. If the generation time (i.e. time between random sampling of gametes/propagules from an infinitely large pool) in these clonal organisms is extremely long, the $M$ estimates may be large even if the migration potential per year is severely limited. As mentioned previously, however, some data suggest that there is a relatively high turnover rate in these populations, which should result in a short average generation time.

Secondly, the estimated $M$-values in the present study do not necessarily reflect high migration rates $(m)$, even for long generation times. The migration rates do not seem to be substantially larger than the mutation rates in the studied populations, indicating that $m$ may be quite low or that the mutation rate is high. It has been proposed that the mutation rate may be high in bryophytes because somatic mutations in the apical cells will be present in all further growth of the stem, including the gametangia, spores, etc. (Shaw, 1990). In the presence of occasional slightly deleterious mutations, however, this should lead to a high mutational load in haploid bryophytes, in which the rate of inherited mutations is increased each generation and recessives cannot be masked in heterozygous genotypes. Therefore, one should rather suspect bryophyte DNA repair systems to be efficient enough to cause the overall mutation rate to be low. If the mutation rate and the migration rate between continents are both low, then the effective population size $(N)$ must be quite large, at least in S. angustifolium. Takahata (1983) has found that it takes a population a time $\tau$, which is approximately the larger of $2 N$ and $1 / m$, to reach an equilibrium between gene flow and genetic drift. Before $\tau$ the genetic composition will be determined primarily by the initial conditions, and after $\tau$ the composition will be determined by $M$. If the studied populations have not reached a gene flow-drift equilibrium because of a large $N$ (and small $\mathrm{m}$ ), then this is a strong candidate to explain the surprisingly high genetic similarity between $S$. angustifolium populations from Norway and from Newfoundland. It could also explain population structure on a local scale.

\section{Conclusion}

In the Conocephalum-Plagiomnium model these two species form a continuum from low to high intra- and interpopulation variation. We understand the model as describing a positive correlation between intra- and interpopulation genetic variation. This could be the outcome of a neutral situation with variation in mutation and recombination rates between taxa, but with significant amounts of drift and limited gene flow in all taxa. Whereas $S$. lindbergii seems to behave in a 'Conocephalum' way, both $S$. angustifolium and $S$. fallax coll. show a lack of positive correlation between intraand interpopulation variation. Akiyama (1994) found a similar disagreement between observed population structure and the Conocephalum-Plagiomnium model for several Leucodon species. It seems that bryophytes exhibit the same variability in population structure as other organisms.

The lack of intercontinental differentiation between S. angustifolium populations raises questions regarding to what degree evolution is taking place. Lack of genetic differentiation between continents is also found in other bryophytes (see e.g. Wyatt et al., 1992, 1993). It might, of course, be that these populations are more differentiated than low resolution isozyme markers are able to detect, and this possibility should be studied using high resolution neutral DNA sequences. On the other hand, if intercontinental populations are not genetically differentiated, this may be explained by: (i) extensive gene flow between continents; (ii) selective forces operating in the populations even though they are not detected by neutrality tests, thereby generating similar genetic makeups; (iii) very long generation times causing high $\theta$ and $M$ estimates even though the per year rates are low; or (iv) low mutation and migration rates and negligible 
effects of random genetic drift, suggesting very high effective population sizes. This latter explanation seems the most satisfying in light of the observed patterns, at least in S. angustifolium. The traditional view of bryophyte evolution was wrong in predicting low genetic variability in bryophyte populations. The main conclusion seems, nevertheless, to be correct: some bryophytes seem to have a very low evolutionary rate.

\section{Acknowledgements}

We thank K. I. Flatberg for extensive help with collection of material and E. Karlin for kindly providing us with samples of $S$. recurvum from New Jersey. B. Pedersen, K. I. Flatberg, J. Mork and two anonymous reviewers commented on the manuscript. Grants were provided by the Research Council of Norway (NFR), project no. 107627/420.

\section{References}

AKIYAMA, H. 1994. Allozyme variability within and among populations of the epiphytic moss Leucodon (Leucodontaceae: Musci). Am. J. Bot., 81, 1280-1287.

ANDERSON, L. E. 1963. Modern species concepts: mosses. Bryologist, 66, 107-119.

CHAKRABORTY, R. AND WEISS, K. M. 1991. Genetic variation of the mitochondrial DNA genome in American Indians is at mutation-drift equilibrium. Am. J. Phys. Anthropol., 86, 497-506.

CORNUET, J. M. AND LUIKART, G. 1997. Description and power analysis of two tests for detecting recent population bottlenecks from allele frequency data. Genetics, 144, 2001-2014.

CRONBERG, N. 1995. Isozyme electrophoresis in Sphagnum: an analysis of methodology. Lindbergia, 17, 69-82.

CRONBERG, N. 1996a. Isozyme evidence of relationships within Sphagnum sect. Acutifolia (Sphagnaceae, Bryophyta). Pl. Syst. Evol., 203, 41-64.

CRONBERG, N. 1996b. Clonal structure and fertility in a sympatric population of the peat mosses Sphagnum rubellum and Sphagnum capillifolium. Can. J. Bot., 74, 1375-1385.

CRUM, H. 1972. The geographic origins of the mosses of North America's eastern deciduous forest. J. Hattori Bot. Lab., 35, 269-298.

CUMMINS, H. AND WYATT, R. 1981. Genetic variability in natural populations of the moss Atrichum angustatum. Bryologist, 84, 30-38.

DANIELS, R. 1993. Phenotypic and genotypic variation in Sphagnum. Adv. Bryol., 5, 31-60.

DOYLE, J. J. AND DOYLE, J. L. 1990. Isolation of plant DNA from fresh tissue. Focus, 12, 13-15.

EWENS, W. J. 1972. The sampling theory of selectively neutral alleles. Theor. Pop. Biol., 3, 87-112.

EXCOFFIER, L., SMOUSE, P. AND QUATTRo, J. 1992. Analysis of molecular variance inferred from metric distances among
DNA haplotypes: application to human mitochondrial DNA restriction data. Genetics, 131, 479-491.

HAIG, E. T. W. 1989. Individual Interactions in Sphagnum populations. Ph.D. Thesis, University of London, London.

HAMRICK, J. L. AND GODT, M. J. W. 1989. Allozyme diversity in plant species. In: Brown, A. H. D., Clegg, M. T., Kahler, A. L. and Weir, B. S. (eds) Plant Population Genetics, Breeding and Genetic Resources, pp. 43-63. Sinauer Associates, Sunderland, MA.

KIMURA, M. AND OHTA, T. 1971. Protein polymorphism as a phase of molecular evolution. Nature, 229, 467-469.

LEWONTIN, R. C. 1964. The interaction of selection and linkage. I. General considerations; heterotic models. Genetics, 49, 49-67.

LEWONTIN, R.C. AND KOJIMA, K. 1960. The evolutionary dynamics of complex polymorphisms. Evolution, 14, 458-472.

LUIKART, G., ALLENDORF, F. W., CORNUET, J. M. AND WILLIAM, B. S. 1998. Distortion of allele frequency distributions provides a test for recent population bottlenecks. J. Hered., in press.

MCQUEEN, C. B. 1985. Spatial pattern and gene flow distances in Sphagnum subtile. Bryologist, 88, 333-336.

MANTEL, N. 1967. The detection of disease clustering and a generalised regression approach. Cancer Res., 27, 209-220.

MITTON, J. B., LINHART, Y. B., STURGEON, K. B. AND HAMRICK, J. L. 1979. Allozyme polymorphisms detected in mature needle tissue of ponderosa pine. J. Hered., 70, 86-89.

NEI, M. 1987. Molecular Evolutionary Genetics. Columbia University Press, New York.

RAYMOND, M. AND ROUSSET, F. 1995. An exact test for population differentiation. Evolution, 49, 1280-1283.

ROHLF, F. J. 1997. NTSYSpc. Numerical Taxonomy and Multivariate Analysis System. Release 2.00. Exeter Software, New York.

SÅSTAD, S. M., STENØIEN, H. K. AND FLATBERG, K. I. 1999. Genetic variability and phylogenetic relationships within the Sphagnum recurvum complex - as revealed by isozyme and RAPD markers. Syst. Bot., in press.

SCHNEIDER, S., KUEFFER, J. M., ROESSLI, D. AND EXCOFFIER, L. 1997. Arlequin: A software for population genetic data analysis. Release 1.1. Genetics and Biometry Laboratory, University of Geneva, Geneva.

SHAw, A. J. 1990. Interclonal variation in morphology, growth rate and copper tolerance in the moss Funaria hygrometrica. Evolution, 44, 441-447.

SHAw, A. J. AND SRODON, M. 1995. Clonal diversity in Sphagnum rubellum Wils. Bryologist, 98, 261-264.

SHAW, A. J., MEAGHER, T. R. AND HARLEY, P. 1987. Electrophoretic evidence of reproductive isolation between two varieties of the moss, Climacium americanum. Heredity, 59, $337-$ 343.

SLATKIN, M. 1994a. An exact test of neutrality based on the Ewens sampling distribution. Genet. Res., 64, 71-74.

SLATKIN, M. 1994b. Linkage disequilibrium in growing and stable populations. Genetics, 137, 331-336.

SLATKIN, M. 1996. A correction to the exact test based on the Ewens sampling distribution. Genet. Res., 68, 259-260. 
STENØIEN, H. K. 1999. Protocols for DNA isolation and random amplified polymorphic DNA (RAPD) analysis on Sphagnum. Lindbergia, in press.

STENØIEN, H., BAKKEN, S. AND FLATBERG, K. I. 1997. Phenotypic variation in the Sphagnum recurvum complex: a cultivation experiment. J. Bryol., 19, 731-750.

STONEBURNER, A., WYATT, R. AND ODRZYKOSKI, I. J. 1991. Applications of enzyme electrophoresis to bryophyte systematics and population biology. Adv. Bryol., 4, 127.

TAKAHATA, N. 1983. Gene identity and genetic differentiation of populations in the finite island model. Genetics, 104, 497512.

WATterson, G. 1978. The homozygosity test of neutrality. Genetics, 88, 405-417.

WEIR, B. S. AND COCKERHAM, C. C. 1984 . Estimating $F$-statistics for the analysis of population structure. Evolution, 38, 13581370.

WENDEL, J. F. AND WEEDEN, N. F. 1989. Visualisation and interpretation of plant isozymes. In: Soltis, D. E. and Soltis, P. S. (eds) Isozymes in Plant Biology, pp 5-45. Dioscorides Press, Portland, OR.

Wright, s. 1951. The genetical structure of populations. Ann. Eugen., 15, 323-354.
WYATT, R. 1982. Population ecology of bryophytes. J. Hattori Bot. Lab., 52, 179-198.

WYATT, R. 1985. Species concepts in bryophytes: input from population biology. Bryologist, 88, 182-189.

WYATT, R. 1994. Population genetics of bryophytes in relation to their reproductive biology. J. Hattori Bot. Lab., 76, 147-157.

WYATT, R., ODRZYKOSKI, I. J. AND STONEBURNER, A. 1989. High levels of genetic variability in the haploid moss Plagiomnium ciliare. Evolution, 43, 1085-1096.

WYATT, R., ODRZYKOSKI, I. J. AND STONEBURNER, A. 1992. Isozyme evidence of reticulate evolution in mosses: Plagiomnium medium is an allopolyploid of P. ellipticum $\times$ P. insigne. Syst. Bot., 17, 532-550.

WYATT, R., ODRZYKOSKI, I. J. AND STONEBURNER, A. 1993. Isozyme evidence proves that the moss Rhizomnium pseudopunctatum is an allopolyploid of $R$. gracile $\times R$. magnifolia Mem. Torrey Bot. Club, 25, 20-34.

YAMAZAKI, T. 1981. Genetic variabilities in natural populations of haploid plant, Conocephalum conicum. I. The amount of heterozygosity. Jap. J. Genet., 56, 373-383.

ZUCKERKANDL, E. AND PAULING, L. 1965. Evolutionary divergence and convergence in proteins. In: Bryson, V. and Vogel, H. J. (eds) Evolving Genes and Proteins, pp. 97-166. Academic Press, New York. 